\title{
Four years of induction/synchronization of estrus in dairy goats: effect on the evolution of eCG binding rate in relation with the parameters of reproduction
}

\author{
Pierre V. DRION ${ }^{\mathrm{a} *}$, Vincent FURTOSs ${ }^{\mathrm{b}}$, Gérard BARIL ${ }^{\mathrm{c}}$, \\ Eduardo MANFREDI ${ }^{\mathrm{d}}$, Frédéric BOUVIER ${ }^{\mathrm{e}}$, Jean-Louis POUGNARD ${ }^{\mathrm{b}}$, \\ Daniel Bernelas ${ }^{\mathrm{b}}$, Paul CAUGNON ${ }^{\mathrm{f}}$, Edmond M. McNAMARA ${ }^{\mathrm{g}}$, \\ Benoît RemYa ${ }^{\mathrm{a}}$, José SuloN ${ }^{\mathrm{a}}$, Jean-François BeCKers ${ }^{\mathrm{a}}$, Lois BodiN ${ }^{\mathrm{d}}$, \\ Bernard LEBEUF ${ }^{b}$
}

\author{
${ }^{a}$ University of Liège, Department of Physiology of Reproduction, Faculty of Veterinary \\ Medicine, Bd. de Colonster 20, 4000 Liège, Belgium \\ b INRA, UEICP, 86840 Rouillé, France \\ c INRA, PRC, 37380 Nouzilly, France \\ d INRA, SAGA, 31326 Castanet-Tolosan, France \\ e INRA, Station Expérimentale Caprine, 18520 Avord, France \\ ${ }^{\mathrm{f}}$ INRA SAPF, Les Verrines, 86600 Lusignan, France \\ $\mathrm{g}$ University of Liège, Biochemistry, Faculty of Medicine, 4000 Liège, Belgium
}

(Received 5 February 2001; accepted 25 October 2001)

\begin{abstract}
Ninety-eight Alpine goats of two herds were followed over 4 years in a program of annual artificial insemination after estrus induction/synchronization, including progestagen administration (vaginal sponge) followed by prostaglandin analog and equine chorionic gonadotrophin (eCG) $48 \mathrm{~h}$ before sponge removal. Goats were sampled every 4 hours from the 16th to the 56th following sponge removal, for determination of LH surge and tested for estrus by the presence of a buck. Seven days after AI, endoscopic examination of the ovaries was performed to determine the number of corpus lutea. Pregnancy diagnosis was performed at day 21-22 post AI by determination of plasma progesterone and at day $40-45$ by ultrasonography. Parturition, number and sex of kids were recorded. All the goats were sampled before and after each treatment, for anti-eCG antibodies screening. Statistical analysis of the results clearly established a significant effect of the treatments on antieCG antibodies. Time of estrus and LH surge were significantly different between herd. The antibodies significantly delayed the time of coming out of estrus as well as the time of LH surge. Two antagonistic effects were evidenced: first, the delayed of time of estrus and time of LH surge in relation with the immune reaction to eCG; secondly, the ahead of time of estrus and time of LH surge during the
\end{abstract}

\footnotetext{
* Correspondence and reprints

E-mail: pvdrion@ulg.ac.be
} 
years of treatment, identical to both herd. The antibodies negatively influenced the percentage of ovulating females as well as kidding rate. Finally, no effect of antibodies on prolificacy was found.

goat / exogenous gonadotrophin / eCG / estrus synchronization / antibody

Résumé - Analyse de 4 années de traitements répétés d'induction/synchronisation de l'œestrus chez la chèvre : effets sur l'évolution de la liaison plasmatique à l'eCG en relation avec les paramètres de reproduction. Quatre-vingt-dix-huit chèvres Alpines ont été suivies dans 2 élevages durant 4 années consécutives dans un programme d'insémination artificielle après induction/synchronisation de l'œstrus incluant l'administration de progestagène (éponge vaginale) puis de prostaglandine et de gonadotropine $(\mathrm{eCG}) 48$ heures avant le retrait de l'éponge. Le début de l'œstrus a été vérifié à l'aide d'un bouc, des prélèvements de sang ont été réalisés toutes les 4 heures en vue de déterminer le moment du pic de LH et un examen endoscopique des ovaires a été effectué 7 jours après l'insémination artificielle pour dénombrer les corps jaunes. Un diagnostic précoce de gestation a été réalisé 21 à 22 jours après I.A. par dosage de la progestérone plasmatique et 40 à 45 jours par échotomographie. Les mises bas ainsi que le nombre et le sexe des chevreaux ont été enregistrés. Des dosages plasmatiques de la liaison à l'eCG ont été réalisés avant et 21 jours après chaque traitement. Les résultats démontrent un effet significatif des traitements sur la production d'anticorps anti-eCG. Une différence significative a été mise en évidence entre les troupeaux pour le moment de venue en œstrus et du pic préovulatoire de LH. De même, les anticorps retardent significativement le moment de venue en œstrus et le pic de LH. Deux effets antagonistes sont mis en évidence. Le premier concerne le retard d'apparition des évènements préovulatoires dus à l'accroissement de la réponse immunitaire à l'eCG. Le second met en évidence une diminution de l'intervalle fin de traitement-évènements préovulatoires au cours des années de traitement, identique pour les 2 troupeaux. Enfin, les anticorps présents influencent négativement le pourcentage de femelles ayant ovulé et la fertilité, mais n'influencent pas la prolificité.

chèvre / gonadotropine exogène / eCG / synchronisation de l'œstrus / réaction immune

\section{INTRODUCTION}

Pituitary and placental gonadotrophins have been used for many years in animal breeding for therapeutic or reproduction management protocols (for a review, see [9]). Previous studies on repeated gonadotrophin administration (eCG/hCG) in rabbits [17], ewes [7] and horses [20] already highlighted the development of resistance to treatment. The authors described the progressive refractoriness of the females to the biological effect of the injected hormone but the absence of cross-reaction between the immune response and the endogenous (pituitary) gonadotrophins [20]. Maurer et al. [17] showed that the neutralizing activity of the serum of the treated females was specific for the injected gonadotrophin with ovaries remaining receptive to other stimulatory treatments.

In goats and ewes, estrus induction/synchronization and superovulation constitute the most common use of gonadotrophins. The equine chorionic gonadotrophin (eCG) is frequently associated with progestagens (fluorogestone acetate, medroxy progesterone acetate or norgestomet) which are administered for a period similar to the lifetime of a cyclic corpus luteum [1]. Baril et al. [3] showed that the eCG binding rate before treatment increased with the rank of treatment and led to an increase in the frequency of late estrus (i.e. coming out $>30 \mathrm{~h}$ after progestagen withdrawal). When eCG binding was higher than $10 \%$, the percentage of late estrus was high and the fertility after AI at a predetermined time decreased 
significantly. Similar results based on concentration of antibodies were obtained by Roy et al. [23].

In order to analyze the effects of repeated gonadotropic treatments on various herd parameters, we followed throughout 4 consecutive years two dairy herds of goats which had never received eCG injections before the experiment. These females were annually subjected to AI after estrus induction (FGA/eCG). This would constitute an objective approach to evaluate the classical scheme of 4-year breeding of dairy goats and the effect of repetition of annual synchronization treatments. With this aim, we recorded various reproductive traits such as time of estrus and LH surge outcome, number of ovulations, pregnancy rate, kidding rate and prolificacy after AI at a predetermined time. We also investigated the immune response of the goats against eCG by measuring eCG binding activity on blood samples collected each year.

\section{MATERIALS AND METHODS}

\subsection{Animals, gonadotrophin treatment and AI}

Hormonal treatments for estrus and ovulation induction/synchronization were administered once a year over 4 years to 98 Alpine goats out of breeding season (August). All the goats in herd 1 (H1; $n=31$ ) were 1 year old and nulliparous at the first treatment. Goats in herd 2 (H2; $n=67$ ) were older (2 to 6 years) and primior multiparous. All goats were submitted for the first time to an estrus synchronization program.

Treatment consisted of a vaginal fluorogestone-acetate (FGA) sponge (Chronogest $^{\mathrm{R}}$; Intervet, France), inserted for 11 days and containing 40 (nulliparous goats) or 45 (primi- and multiparous goats) $\mathrm{mg}$ of FGA. 48 hours before sponge removal, goats were treated with $50 \mu \mathrm{g}$ i.m. of Cloprostenol (Hoechst, France) and eCG (respectively
250 and 400 IU for nulli- and primi/multiparous goats; Folligon ${ }^{\circledR}$; Intervet, Angers, France)

Estrus was monitored by presentation of a buck fitted with an apron every 4 hours from the 16th to the 56th $\mathrm{h}$ following sponge removal. In order to determine the time of LH surge (Elisa kit, Reprokit, Sanofi, France), goats were sampled for blood during the same period, excepted for the first year of experiment in the herd 2 were goats were sampled from the first observation of estrus to the 56th hour. Goats were inseminated once (exocervical way) at the 43rd or 45th h (respectively primi-multi- vs. nulliparous goats) after sponge removal with $100 \times 10^{6}$ of total frozen spermatozoa contained in a $0.25 \mathrm{~mL}$ straw [8].

Ovaries were checked for ovulation by endoscopic examination 7 days after AI.

Determination of plasma progesterone for early pregnancy diagnosis was made at day 21-22 post AI. Trans-abdominal ultrasonography for confirmation of pregnancy was made at day 40-45. Parturitions were observed and number and sex of kids recorded. Goats of our experiment were sampled before receiving any eCG treatment and the plasma checked for eCG binding rate by a sensitive radioimmunoassay (RIA).

Finally, to investigate the eCG binding response (if any) of the goats, blood samples were collected each year for 4 years, just before (at the sponge insertion) and 21 days after each synchronization treatment.

\subsection{Assay}

\subsubsection{Equine Chorionic Gonadotro- phin (eCG) and radiolabeling with ${ }^{125}$ Iodine}

A Folligon preparation provided by Intervet (Organon Oss. Netherlands) was used for the assay. The equine chorionic 
gonadotrophin was purified according to Christakos and Bahl [6]. The biological activity of the purified preparation was 10000 IU per mg as determined by the Steelman and Pohley bioassay [25].

The purified eCG was radioiodinated with ${ }^{125}$ I (Amersham, IMS-30, Gent, Belgium) according to the enzymatic procedure of Thorell and Johansson [26]. In order to obtain a high specific radioactivity and a reliable tracer, $12.5 \mu \mathrm{g}$ of eCG (dry weight lyophilized powder) were iodinated using $1 \mathrm{mCi}$ of ${ }^{125} \mathrm{I}, 1 \mu \mathrm{g}$ of lactoperoxydase (Boehringer Mannheim, Mannheim, Germany) and $10 \mu \mathrm{L}$ of $\mathrm{H}_{2} \mathrm{O}_{2}$ (Perhydrol Merck 1/30000, Darmstadt, Germany). Immediately after the reaction $(4.5 \mathrm{~min})$, the radiolabeled hormone was separated from free ${ }^{125}$ Iodine by chromatography on a Sephadex (Pharmacia, Uppsala, Sweden) G-75 column $(0.9 \times 30 \mathrm{~cm})$ equilibrated with TrisbSA $0.01 \mathrm{M}$, pH 7.6 containing $0.1 \%$ bovine serum albumin (bSA).

\subsection{2. eCG binding detection in plasma samples}

Blood was collected at the jugular vein, stored at $20{ }^{\circ} \mathrm{C}$ during 24 hours and centrifuged $(20 \mathrm{~min}$ at $1500 \mathrm{~g}$ ). Plasma were frozen and stored at $-20{ }^{\circ} \mathrm{C}$ until assay.

All dilutions of plasma or tracer were performed in Tris-bSA buffer $0.025 \mathrm{M}$, pH 7.6 containing BSA $0.1 \%$ and Neomycin sulfate $0.01 \%$. The incubation volume was always $500 \mu \mathrm{L}$. Reagents were added in the following order: $300 \mu \mathrm{L}$ of Tris-bSA buffer, $100 \mu \mathrm{L}$ of each serum diluted 10 times in Tris-bSA buffer, $100 \mu \mathrm{L}$ of ${ }^{125}$ I-eCG corresponding to $10000 \mathrm{cpm}(\mathrm{T})$ or to $1.4 \mathrm{ng}$ of hormone (as determined by the self-displacement method of Roulston [21]).

Incubation was carried out for $16 \mathrm{~h}$ at $20{ }^{\circ} \mathrm{C}$. Thereafter, $100 \mu \mathrm{L}$ of a donkey antigoats immunoglobulin solution were added. Incubation was carried out for 1 additional hour at $20{ }^{\circ} \mathrm{C}$. Then $500 \mu \mathrm{L}$ of $4 \%(\mathrm{w} / \mathrm{v})$ polyethylene glycol (PEG MW 10000
Merck Inc., Darmstadt, Germany) diluted in Tris-bSA buffer were added. The tubes were centrifuged at $2500 \mathrm{~g}$ for $20 \mathrm{~min}$ and the supernatants aspirated.

The pellets were washed with $3 \mathrm{~mL}$ of Tris-bSA buffer and centrifuged at $2500 \mathrm{~g}$ for $15 \mathrm{~min}$. After aspiration of the supernatants, the pellets were counted for radioactivity in a gamma counter with a $60 \%$ efficiency for ${ }^{125} \mathrm{I}$. Non specific binding (NSB) of ${ }^{125} \mathrm{I}-\mathrm{eCG}$ was determined using plasma (in duplicate) obtained from the goats before any administration of the exogenous gonadotrophin.

\subsection{Statistical analysis}

The data are presented in the text as anti-eCG antibody binding rates, which represent the capacity for the serum to bind ${ }^{125} \mathrm{I}-\mathrm{eCG}$ used in the assay. The same data are presented in the curves as binding rate (BR). Binding rates are separated into BR before treatment (BRbe) and binding rates after treatment (BRaf).

Due to the high skewness of the distribution of eCG binding rates, the logarithms of the values plus one: $\log (\mathrm{BRbe})=$ $\ln (\mathrm{BRbe}+1)$, were used for statistical analysis. Factors of variation of eCG binding rates were tested using the Mixed procedure (SAS) [24]. Following Littell et al. [16] we tested different covariance structures to take account of repeated measures. The unstructured covariance or the compound symmetric structure was chosen according to the best value of Schwarz Bayesian Criteria. The herd and the number of treatments were considered as fixed main effects. An eventual age effect could not be tested due to partial confounding between age and number of treatment. The influence of the eCG binding rates (BRbe and BRaf) on delay for LH surge, time of estrus, number of ovulations and number of kids was also analyzed using a similar statistical procedure. The parturition and presence/absence of corpora lutea which are binary variables were 
analyzed by generalized linear model (GENMOD procedure, SAS, [24]). We chose the logit link function and the binomial distribution. We used deviance analysis to test the factor effects (female, treatment, herd, $\mathrm{BRbe}$ and BRaf). The respective chi-square probability values are presented in the text.

\section{RESULTS}

\subsection{Plasma eCG binding rate levels}

For both herds we observed an important increase of the mean values of binding rates before treatment (BRbe) from the 1st to the 4 th treatment (Fig. 1). The binding rates after treatment (BRaf) increased dramatically from the 1 st to the 2 nd treatment. Afterwards, this value remained constant with elevated levels (Fig. 1).

Statistical analysis showed a highly significant effect of treatment $(P<0.01)$ on eCG binding rate (BRbe and BRaf) and a significant effect of herd origin on $\mathrm{BRbe}$ ( $\operatorname{logBR} b e$ of $\mathrm{H} 1>\log \mathrm{BR}$ be of $\mathrm{H} 2, P=0.02$ ). Individual variation of BRaf and BRbe was $63 \%$ and $39 \%$ of total variability respectively.

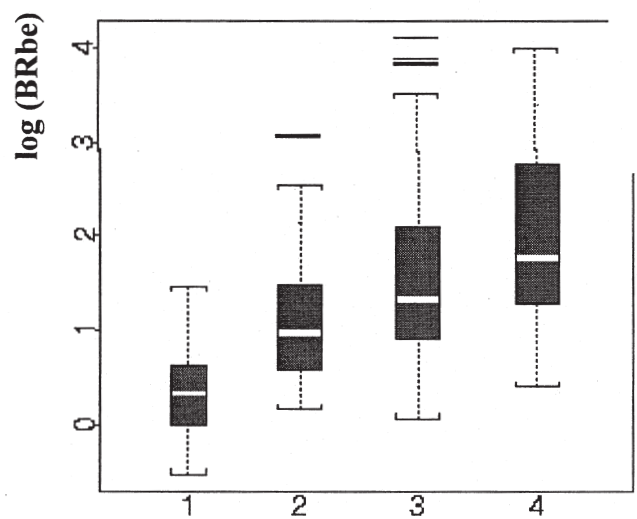

Correlations between binding rate 20 days after eCG injection at a given treatment $\left(\right.$ BRaf $\left._{n}\right)$ and residual binding rate one year later, before the next treatment $\left(\mathrm{BRbe}_{n+1}\right)$ was high $(r=0.71 ; P<0.001)$ and greater than the correlation between the residual binding rate observed before a given treatment $\left(\mathrm{BRbe}_{n}\right)$ and the eCG binding rate a few weeks later, after a new eCG injection $\left(\mathrm{BRaf}_{n}\right): r=0.55(P<0.001)$.

\subsection{Influence of eCG binding and number of treatments on time to estrus after sponge withdrawal}

Most of the estrus were observed before 32 hours (87\%), see Figure 2. Raw data on time to estrus and percentage of females that did not come into estrus from 16th to 56th hours after sponge removal (Tab. I) did not indicate a clear trend for the influence of repeated hormonal treatments on estrus delay. A preliminary analysis of the percentage of 'delayed' females showed significant differences between herds $(P<0.01)$, significant negative effect of BRbe $(P<0.01)$ but no significant effects for the number of treatments. Raw data suggested the existence of interaction between herds and

Figure 1. Boxplot distribution (log) of eCG binding rate before (left) and after (right) estrus synchronization treatments of goats. Boxplot illustrate median, second and third quartile. Whiskers are drawn to nearest value not beyond $1.5 \times$ (inter-quartile range). Horizontal lines are outliers. $X$-axis: number of treatment. $Y$-axis: log of eCG binding rates. 


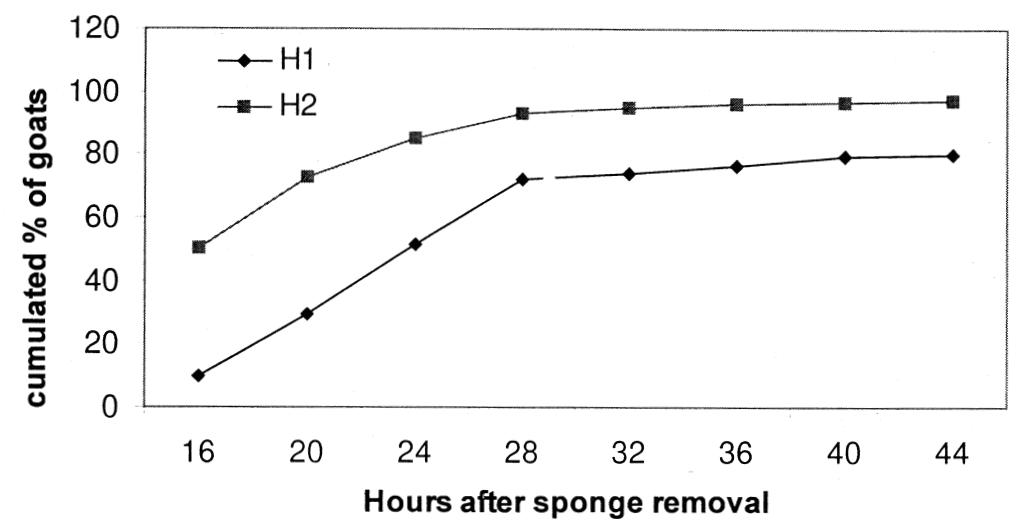

Figure 2. Distribution of cumulated percentages of goats presenting estrus in the observed interval after sponge removal, according to the herd. $X$-axis: time of estrus outcoming (hours after sponge withdrawal).

Table I. Estrus and repetition of treatments in goats.

\begin{tabular}{|c|c|c|c|c|c|c|}
\hline \multirow[t]{2}{*}{ Parameter } & \multirow[t]{2}{*}{ Herd } & \multicolumn{4}{|c|}{ Rank of treatment } & \multirow{2}{*}{$\begin{array}{l}\text { Mean } \\
\text { value }\end{array}$} \\
\hline & & 1 & 2 & 3 & 4 & \\
\hline
\end{tabular}

Interval sponge removal - estrus (hours $\pm \mathrm{SD}$ )

$\begin{array}{llllll}\text { H1 } & 24 \pm 3.9^{\mathrm{a}} & 26 \pm 2.0^{\mathrm{b}} & 22 \pm 6.5^{\mathrm{c}} & 26 \pm 8.8^{\mathrm{c}} & 24.5 \\ \mathrm{H} 2 & 17 \pm 2.0^{\mathrm{a}} & 21 \pm 3.9^{\mathrm{b}} & 20 \pm 6.7^{\mathrm{c}} & 21 \pm 7.3^{\mathrm{c}} & 19.7\end{array}$

$\%$ of females without estrus

$\begin{array}{rccccr}\mathrm{H} 1 & 13 & 16 & 28 & 16 & 18.2 \\ \mathrm{H} 2 & 0 & 9 & 0 & 0 & 2.2\end{array}$

SD: Standard Deviation.

a,b,c Within row, values with different superscripts denote significant differences of comparison between variances.

$\log B$ Rbe for the time to estrus. Accordingly and after the Mixed procedure evaluation, the following model was used:

Time to estrus $=\mu+\alpha_{\text {treatment }}+\beta_{\text {herd }}$

$$
+\gamma_{\text {herd }} \times \operatorname{logBRbe} \text {. }
$$

All effects of this model were found highly significant $(P<0.01)$ and solutions for all effects are presented in Figure 3a. For both herds, the delay for goats to come into estrus increased with the value of log BRbe (the coefficients $\gamma_{\text {herd }} \times \log$ BRbe were 2.6 and
1.1 hours for $\mathrm{H} 1$ and $\mathrm{H} 2$, respectively). The effect of the number of treatments (with data simultaneously adjusted for binding rates) exhibited a decreasing trend: the estimated time to estrus for treatment 1 was about 3 hours later than that estimated for treatment 4 . This trend was regular from year 1 to year 3 and this systematic evolution could be in relation with the effect of ageing, since age could not be modeled directly in this study. Individual variation accounted for $14 \%$ of total variability of time of estrus. 
(a)

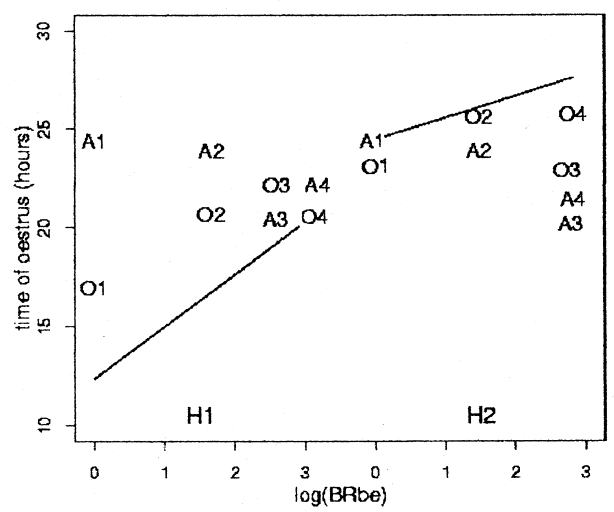

(b)

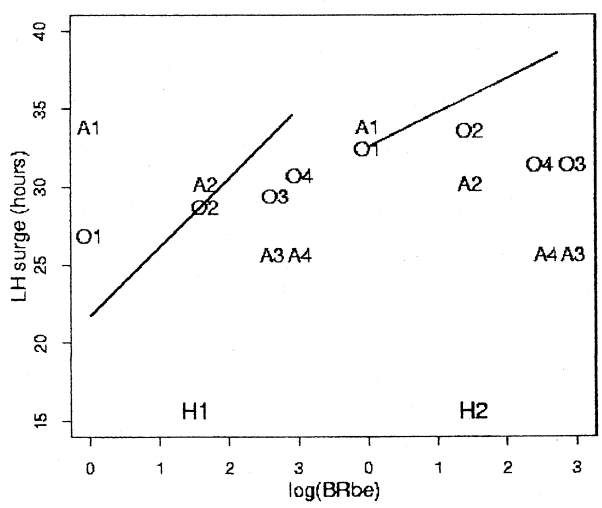

Figure 3. Effect of treatment and eCG binding rate on estrus (a) and LH surge (b) according to mixed procedure of SAS. The respective models used for estrus and LH surge were: Time to estrus $\mu+\alpha_{\text {treatment }}+\beta_{\text {herd }}+\gamma_{\text {herd }} \times \operatorname{logBRbe}$ and Time to LH surge $=\mu+\alpha_{\text {treatment }}+\beta_{\text {herd }}+\gamma_{\text {herd }} \times$ $\operatorname{logBRbe}$. A $(n)$, solution for estrus or LH time and for each treatment (from 1 to 4 ), obtained by mixed procedure. The line, solution obtained by mixed procedure for the interaction herd $x$ $\log \mathrm{BRbe}$. The mean of $\mathrm{A}(n)$ and the corresponding point of the line is the value of the variable (estrus or LH time) predicted by the model. $\mathrm{O}(n)$, the observed mean at each year of treatment (from 1 to 4), for time of estrus and LH surge. The values on $X$-axis (Al... A4, 01... 04) are the mean of $\log B R b e$ at each treatment. For a better understanding of the results, some points closely grouped in (a) - 03, A3, 04 and $\mathrm{A} 4$ in $\mathrm{Hl} ; 01$ and $\mathrm{Al}$ in $\mathrm{H} 2 ; 03, \mathrm{~A} 3$ and $\mathrm{A} 4$ in $\mathrm{H} 2$ - were more clearly separated. The same was done for a better understanding of (b): 02 and A2 in $\mathrm{H} 1 ; \mathrm{A} 3$ and $\mathrm{A} 4$ in $\mathrm{Hl} ; 01$ and $\mathrm{Al}$ in $\mathrm{H} 2 ; 03$ and 04 in $\mathrm{H} 2 ; \mathrm{A} 3$ and $\mathrm{A} 4$ in $\mathrm{H} 2$.

\subsection{Influence of eCG binding and number of treatments on LH surge after sponge withdrawal}

Most of the LH surges appeared before or at the 36th hour $(78.0 \%)$ in both herds and the preovulatory LH surge appeared later in herd 1 (H1) than in herd 2 (H2) (Fig. 4, Tab. II). The observed percentage of females without LH surge from 16th to 56th hours after sponge removal increased from the 1st to the 4th treatment $(P<0.01)$, with important significant differences between herds $(16.7 \%$ in herd 1 and $3.5 \%$ in herd 2 ; $P<0.001$; Tab. II), and a significant negative effect of BRbe $(P<0.01)$.

As for time to estrus, raw data did not suggest a clear influence of the number of treatment on time to $\mathrm{LH}$ surge but indicated possible interaction between herds and logBRbe. Therefore and after Mixed procedure evaluation, the best model to study variation of time to LH surge was:

$$
\begin{aligned}
\text { Time to LH surge }= & \mu+\alpha_{\text {treatment }}+\beta_{\text {herd }} \\
& +\gamma_{\text {herd }} \times \operatorname{logBRbe} .
\end{aligned}
$$

We found a significant effect of number of treatment $(P<0.01)$, of herd $(P<0.01)$ and an interaction between herd and $\log B$ Rbe $(P<0.01)$. Solutions for the effects in the model are in Figure 3b. The time to reach the LH peak decreased with the number of treatment, for data simultaneously adjusted for binding rate, but increased with the increase of the eCG binding rate. The time to reach the LH peak increased with the value of $\log$ BRbe (2.2 and 4.4 for the coefficient $\gamma_{\text {herd }}$, respectively for $\mathrm{H} 1$ and $\mathrm{H} 2$ ), see Figure 3 . The time of LH surge for treatment of rank 1 was about 8 hours later than that for treatment of rank 4 (Fig. 3). Individual variation accounted for $27 \%$ of total variability of time $\mathrm{LH}$ peak. 


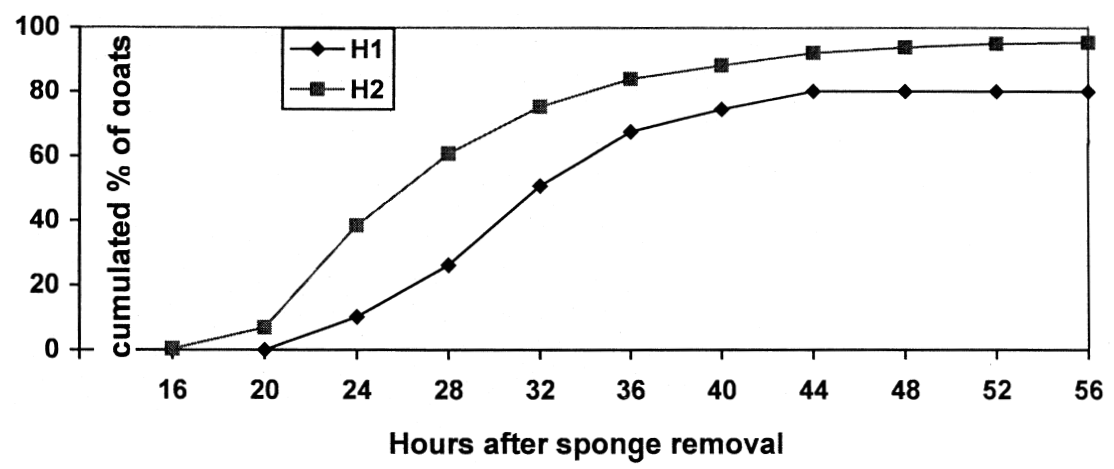

Figure 4. Distribution of cumulated percentages of goats presenting LH surge in the observed interval after sponge removal, according to the herd. Goats were sampled from 16th till 56th $\mathrm{h}$ after sponge removal. The percentages of "no LH" (absence of LH surge in the observed interval) are 19.8 and 4.3, respectively for H1 and H2. X-axis: time of LH surge (hours after sponge withdrawal).

Table II. LH surge and repetition of treatments.

\begin{tabular}{llccll}
\hline Parameter & Herd & \multicolumn{3}{c}{ Rank of treatment } & Mean \\
\cline { 2 - 5 } & & 2 & 3 & 4 & value \\
\hline
\end{tabular}

Interval sponge removal - estrus (hours $\pm \mathrm{SD}$ )

$\begin{array}{llllll}\text { H1 } & 33.0 \pm 5.7^{\mathrm{a}} & 33.6 \pm 4.5^{\mathrm{a}} & 31.4 \pm 5.3^{\mathrm{a}} & 31.6 \pm 6.6^{\mathrm{a}} & 32.4 \\ \mathrm{H} 2 & 26.8 \pm 3.9^{\mathrm{a}} & 29.7 \pm 6.4^{\mathrm{b}} & 29.4 \pm 7.8^{\mathrm{bc}} & 30.1 \pm 8.6^{\mathrm{c}} & 29\end{array}$

$\%$ of females without LH surge

$\begin{array}{rrrrrc}\mathrm{H} 1 & 3.0 & 12.0 & 29.0 & 34.0 & 16.7 \\ \mathrm{H} 2 & 0.0 & 1.0 & 1.0 & 12.0 & 3.5\end{array}$

$\overline{\text { a,b,c Within row, values with different superscripts denote significant differences of comparison between variances. }}$

\subsection{Influence of eCG binding and number of treatments on the fertility after AI}

Observed fertility rates are in Table III. In herd 1 , we observed a decrease in kidding rate from the 1 st to the 4 th treatment $(68$; $56 ; 37 ; 40 \%)$ and an increase in binding rates, from 0 to 27 , which can be associated with the progressive increase of the percentage of $\mathrm{H} 1$ females that did not present an LH surge (1st to 4 th treatment: 3, 12, 29, 34\%; Tab. II). However, in herd 2, raw means of fertility rate remained high after treatment 1 .
The influence of the antibodies on fertility was tested by the following linear "generalized" model:

$$
\begin{aligned}
\text { fertility rate }= & f^{-1}\left(\mu+\alpha_{\text {treatment }}+\beta_{\text {herd }}\right. \\
& \left.+\gamma_{\text {herd }} \times \operatorname{logBRbe}\right),
\end{aligned}
$$

$f$ representing the link function between the observed binary trait and the underlying linear model. A significant effect of the herd was found on the kidding rate (Tab. III; $P=0.01)$. The number of treatments, when data were adjusted simultaneously for BR, was non significant. BRbe was significant $(P<0.01)$ with estimated regression coefficients of -0.92 and -0.16 for herds 1 and 2 , 
Table III. Kidding rate, antibodies level and repetition of treatments.

\begin{tabular}{lccccc}
\hline Parameter & Herd & 1st Treatment & 2nd Treatment & 3rd Treatment & 4th Treatment \\
\hline Kidding rate (\%) & H1 & 68.0 & 56.0 & 37.0 & 40.0 \\
& H2 & 57.0 & 65.0 & 71.0 & 51.0 \\
BRbe & H1 & - & 5.6 & 8.8 & 11.8 \\
& H2 & 1.57 & 3.0 & 6.9 & 11.3 \\
BRaf $(n-1) *$ & H1 & 0 & 4.1 & 26.0 & 27.0 \\
& H2 & 0 & 5.1 & 20.0 & 26.0 \\
\hline
\end{tabular}

* eCG binding rate after treatment one which influence the kidding rate at the treatment two.

respectively. Negative signs highlight the detrimental influence of antibodies on fertility after IA.

AI was performed at a predetermine time after sponge removal. The fertility was significantly influenced by the time of estrus $(P<0.01)$ or time of LH peak $(P<0.01)$, (Tab. IV).

\subsection{Influence of eCG binding on the ovulation}

The percentages of ovulating females from the 1 st to the 4 th treatment were respectively 98.9, 93.8, 95.6 and 94.7. The percentages of anovulating females were $0.5 \%$ and $9 \%$, respectively for $\mathrm{H} 2$ and $\mathrm{H} 1$. The observed mean number of ovulation per female from the 1 st to the 4th treatment was respectively 2.2, 2.0, 2.1 and 1.9.

The influence of the eCG binding rate on the ovulation was studied by the following model:
Number of ovulation $=\mu+\alpha_{\text {treatment }}+\beta_{\text {herd }}$ $+\gamma \times \log$ BRbe.

When anovulating females were included in this model, the number of ovulation was negatively influenced by BRbe $(P<0.01)$ and herd $(P<0.01)$ but no effect of the treatment $(P>0.09)$ was highlighted. BRbe negatively influenced the number of ovulation $(P<0.01)$. Whereas if we did not include theses females in the model, we did not found an effect of eCG binding rate on ovulation.

\subsection{Influence of the antibodies on the prolificacy}

The observed mean number of kids per female from the 1 st to the 4th treatment was respectively $1.6,1.8,1.8$ and 1.8 . The influence of the eCG binding rate on the prolificacy was studied by the following model:

$$
\begin{aligned}
\text { Prolificacy }= & \mu+\alpha_{\text {treatment }}+\beta_{\text {herd }} \\
& +\gamma \times \log B \text { Re } .
\end{aligned}
$$

Table IV. Kidding rate and class of time of estrus and class of time of LH peak.

\begin{tabular}{llllll}
\hline & \multicolumn{5}{c}{ Classes of observations } \\
\cline { 2 - 6 } Fertility & $12 \mathrm{~h}-20 \mathrm{~h}$ & $24 \mathrm{~h}-32 \mathrm{~h}$ & $36 \mathrm{~h}-44 \mathrm{~h}$ & $>48 \mathrm{~h}$ & No observation* \\
\hline Estrus, \% $(n)$ & $60.0(234)$ & $65.0(117)$ & $14.0(15)$ & $50.0(16)$ \\
LH peak, \% $(n)$ & $64.0(16)$ & $64.0(223)$ & $67.0(67)$ & $0(8)$ & $15.0(21)$
\end{tabular}

* Only for the females with presence of CJ. 
We found no effect of the eCG binding rate on the prolificacy but an effect of herd $(P<0.05)$, probably related to the females of herd 1 which were nulliparous at the first treatment.

\section{DISCUSSION}

In agreement with Baril et al. [3] and Roy et al. [23], we observed that the repetition of estrus induction/synchronization in goats by eCG was followed by an increase in the immune response to the hormone. Delayed estrus and LH surge as well as a reduced fertility after artificial insemination accompanied this antibody production. We postulate that the significant decrease in fertility, induced by late estrus and LH peak, was due to the immune response against eCG. Indeed, as previously described by Baril et al. [5] and Roy et al. [23], a lower kidding rate was observed when the time of estrus was later than 32 hours and LH peak more than 44 hours after sponge removal. The interval between LH peak and ovulation was 22 hours [15]. Consequently, in goats with a delayed LH peak and AI performed at the predetermined time of $43 \mathrm{~h}$ after sponge removal, the AI was performed too early to enable the fertilization of ova.

We confirmed the variability of the onset of estrus in dairy goats after synchronization with a progestagen/eCG treatment already described in other studies $[2,4,13$, $19,22]$. The variability of the onset of estrus and LH peak increased significantly with the repetition of treatments (Tabs. I, II). Freitas et al. [13] showed that the timing of estrus and LH surge was less variable after a progestagen treatment than during a natural estrous cycle. Numerous factors are known to influence the time of occurrence of estrus: breed, age, season, type of synchronizing treatment, dose and time of eCG injections, presence of a male as well as body condition [1, 10-12]. Our experiment demonstrated that immune reaction should be recognized as a new major element influencing the time of apparition of estrus in herds submitted to repeated synchronization treatments.

Whereas Roy [23] highlighted that females presenting poor immune response at the first treatment did not show increased immune response at the following eCG administration, we found that the immune response 21 days after a fixed treatment was more correlated with the residual binding rate observed at the following treatment (one year later) $(r=+0.71)$ than with the binding rate present before the considered treatment $(r=+0.55)$. From this observation, it results for each following treatment a partially modified classification of the females according to their immune response.

We found a significant herd effect on reproductive parameters with the repetition of treatments. Estrus and LH surge appeared later in $\mathrm{H} 1$ than in $\mathrm{H} 2$, with percentages of anovulating females being significantly different between herds, respectively 9 and $0.5 \%$ in $\mathrm{H} 1$ and $\mathrm{H} 2$.

The kidding rate decreased progressively from the 1 st to the 4th treatment in H1. In $\mathrm{H} 2$, we observed a low fertility after the 1 st treatment followed by an increase to reach a constant level from the 2 nd to the 3 rd treatment then lower fertility to the 4th treatment. The kidding rate was significantly influenced by the time of estrus and time of LH peak.

We observed an increased immune response against eCG with repetition of treatments, whatever the herd. The influence of these antibodies on reproductive parameters (estrus, LH surge and fertility) differed among the herds, suggesting a possible influence of the females. Firstly, the parity of the females at the first treatment differed between herds. The doses of eCG were respectively 250 and 400 UI for nulli- (H1) and primi/multiparous (H2). Secondly, the variability in ovulatory response to a treatment could be influenced by a modification of seasonal anestrus. Moore and Eppleston 
[18] showed that the use of eCG was not necessary during the breeding season. We can reasonably postulate that the negative effects of circulating antibodies near the breeding season (August) could be modulated by the depth of anestrus at the time of reproduction. Finally, we also suggest that the management of reproduction could introduce some genetic variability between the herds: AI was regularly used in $\mathrm{H} 1$ with subsequent introduction of new genotypes while $\mathrm{H} 2$ was in-bred. So, this herd effect could constitute a part of the endogenous physiology of the animals suggested by Freitas et al. [13] to explain this phenomenon.

The absence of ovulation could partially be related to the increased immune response against eCG. Consequently, it appeared that the decreased fertility that accompanied the increased immune response was not only related to delayed estrus and/or LH surge as described by Baril et al. [3] and Roy et al. [23] but also to this absence of ovulation.

The statistical model used for estrus and LH surge showed two antagonistic effects. The first one concerned the delayed preovulatory events related to the increased immune response. The second one showed a reduced interval between the end of the treatment and the preovulatory events throughout the treatments, which was identical for both herds (Fig. 3). These two underlying and opposite effects could explain the absence of difference we found between treatments concerning the time of estrus and the time of LH surge (Tabs. I, II). The influence of the treatment could in fact probably be related to an effect of ageing that was never described in goats until now.

Females that did not present estrus or LH surge in the observed interval (16-56th hour) but which had corpora lutea, were not included in the statistical analysis. However, the solutions obtained from the statistical model applied for time of estrus and LH surge analysis, were not significantly different when we included those females with a postulated ovulation delay of greater than 56 hours. Nevertheless this phenomenon will be experimentally confirmed.

Our experiment shows the need for careful management of goat herds when goats are repeatedly treated with eCG to increase fertility. Repeated treatments can perturb the biological mechanisms of reproduction. Before new alternatives for ovarian stimulation become available (recombinant glycoproteins with high ratio of bioactivity/ immunogenicity) $[5,14]$, repetition of treatments during the same year should be avoided, and there should be greater importance attached to detection of estrus and to the timing of AI, as an increase in the success rate of treatment will result.

\section{ACKNOWLEDGMENTS}

This work was done in collaboration with the teams of "Bourges" and "Les Verrines" herds. Special thanks to all.

\section{REFERENCES}

[1] Baril G., Saumande J., Hormonal treatments to control time of ovulation and fertility of goats, in: Gruner L., Chabert Y. (Eds), VIIth International Conference on Goats, LIR Press, Ivrysur-Seine, France, 2000, pp. 400-405.

[2] Baril G., Leboeuf B., Saumande J., Synchronization of estrus in goats: the relationship between time of occurrence of estrus and fertility following artificial insemination, Theriogenology 40 (1993) 612-628.

[3] Baril G., Remy B., Leboeuf B., Beckers J.F., Saumande J., Synchronization of oestrus in goats: the relationship between eCG binding in plasma, time occurrence of oestrus and fertility following artificial insemination, Theriogenology 45 (1996) 1553-1559.

[4] Beckers J.F., Remy B., Baril G., Figueiredo J.R., Bureau F., Sulon J., Saumande J., Anti-eCG antibodies are transmitted via the colostrum in goats, Theriogenology 43 (1995) 165.

[5] Boime I., Ben-Menahem D., Glycoprotein hormone structure-function and analog design, Recent Prog. Horm. Res. 54 (1999) 271-289.

[6] Christakos C., Bahl O.P., Pregnant Mare Serum Gonadotrophin. Purification and physiochemical, biological and immunological characterization, J. Biol. Chem. 254 (1979) 4253-4261. 
[7] Clarke I.J., Repeated gonadotrophic stimulation of ewes, New Zeal. Soc. Anim. Prod. 33 (1973) 204.

[8] Corteel J.M., Leboeuf B., Baril G., Artificial breeding of goats and kids induced to ovulate with hormones outside the breeding season, Small Rum. Res. 1 (1988) 19-35.

[9] Drion P.V., Remy B., Houtain J.Y., McNamara M., Baril G., Cognie Y., Heyman Y., Leboeuf B., Theau-Clément M., Desbuleux H., Ectors F.J., Ectors F., Beckers J.F., Utilisation répétée des gonadotropines exogènes dans le contrôle de la reproduction : justifications, relations structure-activité biologique, effets secondaires potentiels, Une synthèse, Ann. Med. Vet. 142 (1998) 373-396.

[10] Evans G., Current topics in artificial insemination of sheep, Aust. J. Biol. Sci. 41 (1988) 103-116.

[11] Freitas V.J.F., Baril G., Bosc M., Saumande J., The influence of ovarian status on response to estrus synchronization treatment in dairy goats during the breeding season, Theriogenology 45 (1996) 1561-1567.

[12] Freitas V.J.F., Baril G., Saumande J., Induction and synchronization of estrus in goats: the relative efficiency of one versus two fluorogestone acetate-impregnated vaginal sponges, Theriogenology 46 (1996) 1251-1256.

[13] Freitas V.J., Baril G., Martin G.B., Saumande J., Physiological limits to further improvement in the efficiency of oestrous synchronization in goats, Reprod. Fertil. Dev. 9 (1997) 551-556.

[14] Joshi L., Murata Y., Wondisford F.E., Szkudlinski M.W., Desai R., Weintraub B.D., Recombinant thyrotropin containing a beta-subunit chimera with the human chorionic gonadotropin-beta carboxy-terminus is biologically active, with a prolonged plasma half-life: role of carbohydrate in bioactivity and metabolic clearance, Endocrinology 136 (1995) 3839-3848.

[15] Leboeuf B., Bernelas D., Pougnard J.L., Baril G., Maurel M.C., Boue P., Terqui M., Time of ovulation after LH peak in dairy goats induced to ovulate with hormonal treatment, European embryo transfer association meeting, Lyon, 1993, p. 226.

[16] Littell R.C., Henry P.R., Ammerman C.B., Statistical analysis of repeated measures data using
SAS procedures, J. Anim. Sci. 76 (1998) 1216-1231.

[17] Maurer R.R., Hunt W.L., Foote R.H., Repeated superovulation following administration of exogenous gonadotropins in Dutch-belted rabbits, J. Reprod. Fertil. 15 (1968) 93-102.

[18] Moore N.W., Eppleston J., The control of oestrus, ovulation and fertility in relation to artificial insemination in the angora goat, Aust. J. Agric. Res. 30 (1979) 965-972.

[19] Remy B., Baril G., Vallet J.C., Dufour R., Chouvet C., Saumande J., Chupin D., Beckers J.F., Are antibodies responsible for a decrease superovulatory response in goats which have been treated repeatedly with porcine follicle-stimulating hormone?, Theriogenology 36 (1991) 389-399.

[20] Roser J.F., Kiefer B.L., Evans J.W., Neelly D.P., Pacheco C.A., The development of antibodies to human chorionic gonadotropin following its repeated injections in the cyclic mare, J. Reprod. Fertil. 27 (1979) 173-179.

[21] Roulston J.E., Validation of the self-displacement technique for estimation of specific radioactivity of radioimmunoassay tracers, Ann. Clin. Biochem. 16 (1979) 26-29.

[22] Rowe J.D., East N.E., Comparison of two sources of gonadotropin for estrus synchronization in does, Theriogenology 45 (1996) 1569-1575.

[23] Roy F., Maurel M.C., Combes B., Vaiman D., Cribiu E.P., Lantier I., Pobel T., Deletang F., Combarnous Y., Guillou F., The negative effect of repeated equine chorionic gonadotropin treatment on subsequent fertility in Alpine goats is due to a humoral immune response involving the major histocompatibility complex, Biol. Reprod. 60 (1999) 805-813.

[24] S.A.S./STAT, User's Guide Release 6.03., S.A.S. Inst. Inc., Cary, NC, 1988.

[25] Steelman S.L., Pohley F.M., Assay of the follicle stimulating hormone based on the augmentation with human chorionic gonadotropin, Assay on FSH 53 (1953) 604-616.

[26] Thorell J.I., Johansson B.G., Enzymatic iodination of polypeptides with ${ }^{125}$ I to high specific activity, Biochim. Biophys. Acta 251 (1971) 363-369. 